\title{
KARAKTERISASI MORFOMETRIK DAN BOBOT BADAN PADA SAPI BALI DAN SIMBAL DI KECAMATAN BANGKO KABUPATEN MERANGIN
}

\author{
ZAFITRA, A., GUSHAIRIYANTO, H. EDIYANTO DAN DEPISON* \\ Fakultas Peternakan Universitas Jambi \\ Program Studi Peternakan Fakultas Peternakan Universitas Jambi \\ Jl. Jambi - Ma. Bulian KM. 15 Mendalo Indah, Jaluko, Muaro Jambi, Jambi \\ *Coressponding author: depison.nasution@yahoo.com
}

\begin{abstract}
ABSTRAK
Penelitian ini bertujuan untuk mengetahui hubungan antara karateristik morfometrik dan bobot badan sapi bali dan sapi simbal baik jantan maupun betina. Metode yang digunakan adalah survey. Teknik pengambilan sampel secara purpossive sampling, umur ternak yang digunakan adalah ternak umur $\mathrm{I}_{1}$ dan betina tidak dalam keadaan bunting. Jumlah sampel 60 ekor ternak sapi bali dan 60 ekor ternak sapi simbal. Data yang dihimpun: bobot badan, panjang badan, tinggi pundak, lingkar dada, dalam dada, lebar dada, tinggi pinggul, dan lingkar kanon. Data yang diperoleh dianalisis menggunakan uji t, Analisis Komponen Utama, serta analisis regresi dan korelasi. Hasil penelitian bobot badan dan ukuran-ukuran tubuh sapi bali dan sapi simbal berbeda nyata $(\mathrm{P}<0,05)$. Rataan bobot badan sapi bali jantan dan betina adalah 203,58 \pm 18,68 kg, 190,43 $\pm 11,16 \mathrm{~kg}$ lebih rendah dari sapi simbal jantan dan betina adalah 379,883 \pm 49,14 kg, 350,033 $\pm 31,41 \mathrm{~kg}$. Faktor penentu ukuran tubuh sapi bali dan sapi simbal jantan dan betina adalah lingkar dada. Korelasi tertinggi antara ukuran-ukuran tubuh dengan bobot badan pada sapi bali dan sapi simbal jantan dan betina adalah lingkar dada. Kesimpulan, karakteristik morfometrik dan bobot badan sapi bali lebih rendah dibandingkan dengan sapi simbal.
\end{abstract}

Kata kunci: ukuran-ukuran tubuh, analisis komponen utama (AKU), sapi bali, sapi simbal

\section{CHARACTERIZATION OF MORPHOMETRIC AND BODY WEIGHT BALI CATTLE AND SIMBAL IN BANGKO MERANGIN DISTRICT}

\begin{abstract}
The purpose of this study was to determine the morphometric characteristics and body weights of bali cattle and simbal cattle as well as to determine the relationship between body measurements with body weights of bali cattle and simbals both male and female. The method used is a survey. The sampling technique was purposive sampling, which is the age of I1 and was not pregnant. The number of samples was 60 bali cattle and 60 simbal cattle. Data collected: body weight, body length, shoulder height, chest circumference, chest depth, chest width, hip height, canon circumference. Data obtained were analyzed using t-test, Principal Component Analysis, and regression and correlation analysis. The results showed that body weight and body measurements of bali cattle were significantly different $(\mathrm{P}<0,05)$ from simbal cattle. The body weights of male and female bali cattle were $203.58 \pm 18.68 \mathrm{~kg}$, $190.43 \pm 11.16 \mathrm{~kg}$ lower than those of the simbal male and female respectively, $379.883 \pm 49.14 \mathrm{~kg}, 350.033 \pm 31.41 \mathrm{~kg}$ The determining factor for the body size of bali cattle and simbals of male and female cattle is chest circumference. The correlation between body measurements with body weight in bali cattle and simbal of male and female cattle is the circumference of the chest. The conclusion of the research is morphometric characteristics and bodyweight of bali cattle are lower than simbals.
\end{abstract}

Keywords : body measures, principal component analysis (AKU), bali cattle, simbal cattle 


\section{PENDAHULUAN}

Indonesia merupakan negara yang dikenal sebagai salah satu negara yang memiliki kekayaan sumber daya genetik. Salah satu sumber daya genetik tersebut adalah keanekaragaman ternak sapi lokal. Salah satu daerah dengan perkembangan ternak sapi lokal di Provinsi Jambi adalah di Kabupaten Merangin terutama di daerah Kecamatan Bangko dengan populasi ternak sapi lokal yang banyak dipelihara yaitu ternak sapi bali

Sapi bali adalah sapi potong hasil domestikasi dari banteng liar dan merupakan salah satu plasma nuftah yang cukup potensial untuk dikembangkan. Sapi bali memiliki keunggulan dalam hal tingkat adaptasi yang tinggi. Namun sapi bali ini memiliki kekurangan berupa pertambahan bobot hidup harian rendah dan kurang responsif bila diberi pakan berkualitas (Ahmad et al., 2004). Salah satu upaya yang dapat dilakukan untuk meningkatkan mutu genetik sapi bali melalui program inseminasi buatan (IB) (Depison, 2010). Inseminasi Buatan (IB) merupakan salah satu teknologi reproduksi untuk meningkatkan mutu genetik ternak dalam waktu yang pendek dan dapat menghasilkan anak dengan kualitas baik (Dewantari et al., 2020).

Salah satu upaya yang dapat dilakukan untuk mendapatkan informasi dasar tentang mutu genetik ternak diantaranya dapat dilihat dari karakterisasi karakteristik morfometrik. Morfometrik merupakan studi yang berhubungan dengan variasi dan perubahan ukuran tubuh ternak serta bermanfaat untuk mengetahui dan mendeskripsikan potensi ternak secara kuantitatif (Takandjandji dan Sawitri, 2015). Karakteristik morfometrik dapat diukur melalui: bobot badan, panjang badan, tinggi pundak, lingkar dada, dalam dada, lebar dada, tinggi pinggul, dan lingkar kanon. Informasi karakteristik morfometrik penting diketahui karena dapat digunakan dalam rangka pelestarian plasma nutfah ternak lokal dan bahan pertimbangan seleksi ternak lokal dimasa yang akan datang. Karakteristik morfometrik berkorelasi positif dengan bobot badan seiring bertambahnya ukuranukuran tubuh maka diikuti dengan bertambahnya bobot badan (Trisnawanto et al., 2012).

Berdasarkan uraian di atas maka dilakukan penelitian tentang karakterisasi sifat morfometrik dan bobot badan sapi bali dan sapi simbal di Kecamatan Bangko Kabupaten Merangin.

\section{MATERI DAN METODE}

Materi penelitian adalah ternak sapi bali dan sapi simbal jantan dan betina. Metode yang digunakan adalah survey dengan pengambilan sampel secara langsung oleh peneliti. Teknik pengambilan sampel secara purpossive sampling yaitu sapi umur $\mathrm{I}_{1}$ (1-2 tahun) dan betina tidak dalam keadaan bunting. Jumlah sampel sebanyak 60 ekor ternak sapi bali dan 60 ekor ternak sapi simbal. Peralatan yang digunakan adalah tongkat ukur, alat tulis, pita ukur, kamera digital dan timbangan. Data yang dihimpun meliputi; bobot badan, panjang badan, tinggi pundak, lingkar dada, dalam dada, lebar dada, lingkar kanon dan tinggi pinggul.

\section{Analisis Data}

Data yang telah dihimpun dikelompokkan berdasarkan bangsa dan jenis kelamin sapi bali dan sapi simbal. Selanjutnya perbedaan bobot badan, panjang badan, tinggi pundak, lingkar dada, dalam dada, lebar dada, lingkar kanon dan tinggi pinggul dianalisis dengan menggunakan uji beda rata-rata (uji-t) dengan rumus sebagai berikut:

$$
\mathrm{t}=\frac{\bar{X}_{1}-\bar{X}_{2}}{\sqrt{\frac{\sum\left(X_{J 1}-\bar{X}_{1}\right)^{2}}{n_{1}\left(n_{1}-1\right)}+\frac{\sum\left(X_{J 2}-\bar{X}_{2}\right)^{2}}{n_{2}\left(n_{2}-1\right)}}}
$$

Keterangan :

$\mathrm{t} \quad=$ nilai $\mathrm{t}$ hitung

$\bar{X} \bar{X} i i=$ rataan sampel pada kelompok pertama,

$\bar{X} \bar{X}_{2} \quad=$ rataan sampel pada kelompok kedua,

$X_{j 1} X_{j 1}=$ nilai pengamatan ke-J pada kelompok pertama

$X_{j 2} X_{j 2}=$ nilai pengamatan ke-J pada kelompok kedua

$\mathrm{n}_{1} \quad=$ jumlah sampel pada kelompok pertama, dan

$\mathrm{n}_{2} \quad=$ jumlah sampel pada kelompok kedua.

Kaidah keputusan:

Terima Ho bila t-hitung $\leq \mathrm{t}$ tabel

Terima H1 bila t-hitung $>t$ tabel

Analis Komponen Utama (AKU) digunakan untuk mengetahui faktor penentu ukuran dan faktor penentu bentuk pada sapi bali dan sapi simbal jantan dan betina. Model matematika AKU sesuai petunjuk Gaspersz (2006) dengan rumus sebagai berikut:

$$
Y j=a_{1 j} X_{1}+a_{2 j} X_{2}+a_{3 j} X_{3}+\ldots \ldots+a_{7 j} X
$$

Keterangan :

$\mathrm{Y}_{\mathrm{j}} \quad=$ komponen utama ke-j $(\mathrm{j}=1,2 ; 1=$ ukuran, $2=$ bentuk )

$\mathrm{X}_{1,2,3 \ldots} \quad=$ peubah ke $1,2,3 \ldots .7$

$a_{i j, 2 j, 3 j, . .}=$ vektor eigen variable ke-i $(1,2,3, \ldots .7)$ dan Komponen utama ke j

Pengolahan data dilakukan dengan menggunakan perangkat lunak statistika Minitab 18.

Analisis regresi dan korelasi digunakan untuk mengetahui hubungan dan keeratan hubungan antara ukuran-ukuran tubuh dengan bobot badan, dianalisis sesuai petunjuk Gaspersz (1992) dengan rumus: 


$$
Y j=a_{1 j} X_{1}+a_{2 j} X_{2}+a_{3 j} X_{3}+\ldots \ldots+a_{7 j} X
$$

Keterangan:

$\mathrm{Y}=$ Bobot Badan

$\mathrm{b}_{\mathrm{o}}=$ Konstanta

$\mathrm{b}_{1}=$ Koefisien regresi dari panjang badan $\left(\mathrm{X}_{1}\right)$

$\mathrm{b}_{2}=$ Koefisien regresi dari tinggi pundak $\left(\mathrm{X}_{2}\right)$

$\mathrm{b}_{3}=$ Koefisien regresi dari lingkar dada $\left(\mathrm{X}_{3}\right)$

$\mathrm{b}_{4}=$ Koefisien regresi dari dalam dada $\left(\mathrm{X}_{4}\right)$

$\mathrm{b}_{5}=$ Koefisien regresi dari lebar dada $\left(\mathrm{X}_{5}\right)$

$\mathrm{b}_{6}=$ Koefisien regresi dari lingar kanon $\left(\mathrm{X}_{6}\right)$

$\mathrm{b}_{7}=$ Koefisien regresi dari tinggi pinggul $\left(\mathrm{X}_{7}\right)$

$$
\mathrm{Y}=\mathrm{b}_{0}+\mathrm{b}_{1} \mathrm{X}_{1}+\mathrm{b}_{2} \mathrm{X}_{2}+\mathrm{b}_{3} \mathrm{X}_{3}+\ldots \ldots+\mathrm{b}_{19} \mathrm{X}_{18}
$$

Keterangan:

$r_{x y}=$ Korelasi

$\mathrm{X}^{x y}=$ Ukuran-ukuran tubuh

$\mathrm{Y}=$ Bobot badan

\section{HASIL DAN PEMBAHASAN}

\section{Bobot Badan Sapi Bali dan Sapi Simbal Jantan dan Betina di Kecamatan Bangko}

Bobot badan sapi bali dan sapi simbal jantan dan betina di Kecamatan Bangko dapat dilihat pada Tabel 1.

Tabel 1. Rata-rata bobot badan dan pertambahan bobot badan sapi

\begin{tabular}{|c|c|c|}
\hline \multirow{2}{*}{ Uraian } & \multicolumn{2}{|c|}{ Bangsa } \\
\hline & Sapi bali (kg) & Sapi simbal (kg) \\
\hline \multicolumn{3}{|l|}{ Bobot Badan (BB) } \\
\hline Jantan & $203,58 \pm 18,68^{a}$ & $379,883 \pm 49,14^{b}$ \\
\hline Betina & $190,43 \pm 11,16^{a}$ & $350,033 \pm 31,4^{b}$ \\
\hline
\end{tabular}
bali dan sapi simbal

Keterangan : Huruf yang berbeda pada baris yang sama berbeda nyata $(P<0,05)$

Data pada Tabel 1 menunjukkan bahwa hasil analisis uji beda rata-rata bobot badan sapi bali berbeda nyata $(\mathrm{P}<0,05)$ dengan sapi simbal. Bobot badan sapi bali jantan dan betina secara berurutan adalah 203,58 \pm $18,68 \mathrm{~kg}, 190,43 \pm 11,16 \mathrm{~kg}$ lebih rendah dari pada sapi simbal jantan dan betina yang secara berurutan adalah $379,883 \pm 49,14 \mathrm{~kg}, 350,033 \pm 31,41 \mathrm{~kg}$, Perbedaan bobot badan ini diduga karena adanya pengaruh bangsa dan hormon pada jantan dan betina. Depison (2010) menyatakan bahwa bobot badan bali vs bali pada umur 1 tahun adalah $108,61 \pm 20,60 \mathrm{~kg}$ lebih rendah jika dibandingkan dengan persilangan sapi bali vs simmental umur 1 tahun adalah 131,61 $\pm 27,78 \mathrm{~kg}$. Perbedaan bobot badan jantan dan betina baik pada sapi bali maupun sapi simbal diduga karena adanya pengaruh hormon androgen pada ternak jantan yaitu suatu hormon kelamin yang berfungsi menstimulasi sintesis protein dan memacu pertumbuhan (Hamdani et al,. 2017).

\section{Karakteristik Morfometrik Sapi Bali dan Sapi Simbal di Kecamatan Bangko}

Karakteristik morfometrik sapi bali dan sapi simbal jantan dan betina dapat dilihat pada Tabel 2.

Tabel 2. Rataan kakteristik morfometrik sapi bali dan sapi simbal

\begin{tabular}{lcc}
\hline \multirow{2}{*}{ Uraian } & \multicolumn{2}{c}{ Bangsa } \\
\cline { 2 - 3 } Panjang Badan, cm & \multicolumn{2}{c}{ Bali } \\
- Jantan & $113,18 \pm 3,31^{\mathrm{a}}$ & $136,46 \pm 6,27^{\mathrm{b}}$ \\
- Betina & $104,10 \pm 2,79^{\mathrm{a}}$ & $131,36 \pm 4,75^{\mathrm{b}}$ \\
Tinggi Pundak, cm & & \\
- Jantan & $104,85 \pm 4,70^{\mathrm{a}}$ & $125,30 \pm 5,18^{\mathrm{b}}$ \\
- Betina & $102,83 \pm 2,57^{\mathrm{a}}$ & $120,63 \pm 3,14^{\mathrm{b}}$ \\
Lingkar Dada, cm & & \\
- Jantan & $139,78 \pm 4,50^{\mathrm{a}}$ & $162,53 \pm 8,04^{\mathrm{b}}$ \\
- Betina & $127,60 \pm 4,47^{\mathrm{a}}$ & $161,56 \pm 5,99^{\mathrm{b}}$ \\
Dalam Dada, cm & & \\
- Jantan & $47,53 \pm 2,68^{\mathrm{a}}$ & $51,70 \pm 2,66^{\mathrm{b}}$ \\
- Betina & $43,00 \pm 2,10^{\mathrm{a}}$ & $51,70 \pm 1,34^{\mathrm{b}}$ \\
Lebar Dada, cm & & \\
- Jantan & $32,96 \pm 2,25^{\mathrm{a}}$ & $43,76 \pm 3,13^{\mathrm{b}}$ \\
- Betina & $30,03 \pm 1,82^{\mathrm{a}}$ & $40,33 \pm 1,23^{\mathrm{b}}$ \\
Tinggi Pinggul, cm & & \\
- Jantan & $109,85 \pm 3,47^{\mathrm{a}}$ & $128,30 \pm 3,54^{\mathrm{b}}$ \\
- Betina & $105,03 \pm 3,13^{\mathrm{a}}$ & $127,26 \pm 2,47^{\mathrm{b}}$ \\
Lingkar Kanon, cm & & \\
- Jantan & $14,18 \pm 0,66^{\mathrm{a}}$ & $19,93 \pm 0,94^{\mathrm{b}}$ \\
- Betina & $13,10 \pm 0,63^{\mathrm{a}}$ & $17,58 \pm 1,06^{\mathrm{b}}$ \\
\hline
\end{tabular}

Keterangan : Huruf yang berbeda pada baris yang sama berbeda nyata $(P<0,05)$

Data yang disajikan pada Tabel 2 menunjukkan bahwa karakteristik morfometrik ukuran-ukuran tubuh sapi bali jantan dan betina berbeda nyata $(\mathrm{P}<0,05)$ dibandingkan sapi simbal. Perbedaan ini diduga karena adanya perbedaan bangsa antara kedua bangsa sapi, dimana pada sapi simbal memiliki darah sapi simmental yang dikenal memiliki ukuran-ukuran yang lebih besar dari sapi bali. Depison (2010) menyatakan bahwa ukuran panjang badan, lingkar dada, tinggi pundak sapi bali vs bali umur 365 hari secara berurutan adalah $91,76 \mathrm{~cm}$, 122,55 cm, 90,22 cm lebih rendah jika dibandingkan ukuran panjang badan, lingkar dada, tinggi pundak sapi bali vs simmental umur 365 hari secara berurutan adalah 111,27 cm, 150,465 cm, 109,23 cm. Putra (2017) menyatakan bahwa persilangan antara dua bangsa akan mewariskan masing-masing sebesar 50\% sifat kepada turunanya. Faktor genetik berpengaruh cukup besar terhadap ukuran-ukuran tubuh pada ternak (Gunawan et al., 2008).

Karakteristik Morfometrik Penentu Ukuran dan
Bentuk Tubuh Sapi bali dan Sapi simbal Jantan
dan Betina di Kecamatan Bangko Kabupaten
Merangin
$\quad$ Karakteristik morfometrik penentu ukuran dan bentuk tubuh sapi bali dan sapi simbal jantan dan betina dapat dilihat pada Tabel 3 . 
Tabel 3. Penentu ukuran dan bentuk tubuh sapi bali dan sapi simbal jantan, betina di Kecamtan Bangko Kabupaten Merangin

\begin{tabular}{|c|c|c|c|c|}
\hline Uraian & & Persamaan & KT (\%) & $\Lambda$ \\
\hline \multirow[t]{2}{*}{ Sapi bali Jantan } & Penentu Ukuran Tubuh & $=0,395 \mathrm{~PB}+0,253 \mathrm{TP}+\mathbf{0}, \mathbf{4 0 1} \mathrm{LD}+0,397 \mathrm{DaD}+0,379 \mathrm{LeD}+0,398 \mathrm{LK}+0,400 \mathrm{Tpi}$ & 84,20 & 5,89 \\
\hline & Penentu Bentuk Tubuh & $=-0,109 \mathrm{~PB}+\mathbf{0 , 9 6 1} \mathrm{TP}-0,031 \mathrm{LD}-0,013 \mathrm{DaD}-0,182 \mathrm{LeD}-0,097 \mathrm{LK}-0,088 \mathrm{Tpi}$ & 9,60 & 0,67 \\
\hline \multirow[t]{2}{*}{ Sapi bali Betina } & Penentu Ukuran Tubuh & $=0,395 \mathrm{~PB}+0,213 \mathrm{TP}+\mathbf{0}, \mathbf{4 0 7} \mathrm{LD}+$ 0,404 DaD + 0,395 LeD + 0,386 LK + 0,406 Tpi & 84,20 & 5,89 \\
\hline & Penentu Bentuk Tubuh & $=-$ 0,216 PB + 0,964 TP - 0,041 LD - 0,121 DaD - 0,013 LeD - 0,046 LK - 0,076 Tpi & 11,30 & 0,78 \\
\hline \multirow[t]{2}{*}{ Sapi simbal Jantan } & Persamaan Ukuran Tubuh & $=0,237 \mathrm{~PB}+0,427 \mathrm{TP}+\mathbf{0}, \mathbf{4 3 7} \mathrm{LD}+0,410 \mathrm{DaD}+0,280 \mathrm{LeD}+0,409 \mathrm{LK}+0,397 \mathrm{TPi}$ & 59,3 & 4,15 \\
\hline & Persamaan Bentuk Tubuh & $=\mathbf{0 , 6 4 0} \mathrm{PB}-0,249 \mathrm{TP}+0,208 \mathrm{LD}-0,150 \mathrm{DaD}+0,549 \mathrm{LeD}-0,275 \mathrm{LK}-0,293 \mathrm{Tpi}$ & 13,4 & 0,93 \\
\hline \multirow[t]{2}{*}{ Sapi simbal Betina } & Persamaan Ukuran Tubuh & $=0,359 \mathrm{~PB}+0,366 \mathrm{TP}+\mathbf{0 , 4 2 6} \mathrm{LD}+0,386 \mathrm{DaD}+0,356 \mathrm{LeD}+0,380 \mathrm{LK}+0,368 \mathrm{Tpi}$ & 59,0 & 4,12 \\
\hline & Persamaan Bentuk Tubuh & $=0,353 \mathrm{~PB}+\mathbf{0 , 4 3 6 \mathrm { TP }}-0,323 \mathrm{LD}-0,493 \mathrm{DaD}-0,232 \mathrm{LeD}-0,311 \mathrm{LK}-0,432 \mathrm{Tpi}$ & 11,4 & 0,79 \\
\hline
\end{tabular}

Keterangan :

PB = Panjang Badan, TP = Tinngi Pundak, LD = Lingkar Dada, DaD = Dalam Dada, dan LeD = Lebar Dada, LK = Lingkar Kanon, Tpi $=$ Tinggi Pinggul, KT= Keragaman Total, $\lambda=$ Nilai Eigen

Data yang disajikan pada Tabel 3 menunjukkan bahwa keragaman total komponen utama yang disetarakan dengan ukuran tubuh sapi bali jantan dan betina adalah $84.20 \%$. Persentase ini termasuk nilai keragaman terbesar diantara komponen utama. Hasil penelitian ini tidak jauh berbeda dengan penelitian Hikmawaty et al. (2014) yang menyatakan persentase keragaman total sapi bali adalah 84,1\%

Variabel tertinggi komponen utama ukuran tubuh sapi bali dan sapi simbal jantan maupun betina adalah lingkar dada. Artinya lingkar dada dapat dijadikan sebagai penciri ukuran pada sapi bali dan sapi simbal jantan maupun betina karena memiliki hubungan timbal balik terbesar terhadap persamaan ukuran. Rataan ukuran linier tertinggi tubuh pada sapi bali adalah lingkar dada (Baharun et al., 2017)

Variabel komponen utama bentuk tubuh sapi bali jantan dan betina serta sapi simbal betina adalah tinggi pundak sedangkan sapi simbal jantan adalah panjang badan. Artinya tinggi pundak dapat dijadikan penciri bentuk pada sapi bali jantan dan betina serta sapi simbal betina, sedangkan panjang badan dapat dijadikan penciri bentuk pada sapi simbal jantan karena memiliki hubungan timbal balik terbesar terhadap persamaan bentuk. Hasil penelitian ini sejalan dengan penelitian Hikmawaty et al. (2014) yang menyatakan bahwa penciri bentuk terhadap skor ukuran dan bentuk pada ukuran-ukuran tubuh adalah lingkar dada dan panjang badan.

\section{Regresi dan Korelasi Ukuran-Ukuran Tubuh Dengan Bobot Badan Sapi Bali dan Sapi Simbal}

Analisis regresi menunjukkan bahwa ukuranukuran tubuh sapi bali jantan dan betina berpengaruh nyata $(\mathrm{P}<0,05)$ terhadap bobot badan. Artinya besar kecilnya ukuran-ukuran tubuh akan mempengaruhi besar kecilnya bobot badan, persamaan regresi sapi bali jantan dan betina secara umum adalah:

Jantan : BB $=-428,9+0,357 \mathrm{~PB}+0,057 \mathrm{TP}+2,805 \mathrm{LD}$ - 0,512 DaD - 0,148 LeD - 2,79 LK + 2,394 Tpi

Betina : $\mathrm{BB}=-74,1+0,984 \mathrm{~PB}+0,158 \mathrm{TP}+0,930 \mathrm{LD}+$ 3,563 DaD - 0,906 LeD + 5,48 LK - 1,635 Tpi
Analisis regresi secara parsial panjang badan, tinggi pundak, lingkar dada, dalam dada, lebar dada, lingkar kanon dan tinggi pinggul sapi bali jantan secara berurutan adalah $\mathrm{BB}=-397,6+5,312 \mathrm{~PB}, \mathrm{BB}=-35,4+$ $2,279 \mathrm{TP}, \mathrm{BB}=-364,8+4,066 \mathrm{LD}, \mathrm{BB}=-103,4+6,459$ $\mathrm{DaD}, \mathrm{BB}=-38,0+7,329 \mathrm{LeD}, \mathrm{BB}=-171,0+26,41 \mathrm{LK}, \mathrm{BB}$ $=-362,4+5,153 \mathrm{Tpi}$, sedangkan sapi bali betina adalah $\mathrm{BB}=-207,5+3,823 \mathrm{~PB}, \mathrm{BB}=-5.0+1,900 \mathrm{TP}, \mathrm{BB}=$ $-122,6+2,4529 \mathrm{LD}, \mathrm{BB}=-32,5+5,149 \mathrm{DaD}, \mathrm{BB}=23,6$ $+5,554 \mathrm{LeD}, \mathrm{BB}=-26,4+16,56 \mathrm{LK}, \mathrm{BB}=-169,0+3,422$ Tpi. Artinya penambahan $1 \mathrm{~cm}$ pada setiap ukuranukuran tubuh akan menaikan bobot badan sesuai dengan nilai koefsienya. Ni'am et al. (2012) menyataan bahwa penambahan $1 \mathrm{~cm}$ pada setiap ukuran-ukuran tubuh akan menaikan bobot badan sesuai dengan nilai koefsien masing-masing ukuran tubuh.

Analisis regresi menunjukkan bahwa ukuran-ukuran tubuh sapi simbal jantan dan betina berpengaruh nyata $(\mathrm{P}<0,05)$ terhadap bobot badan. Artinya bahwa besar kecilnya ukuran-ukuran tubuh akan mempengaruhi besar kecilnya bobot badan sapi simbal jantan dan betina. Persamaan regresi sapi bali jantan dan betina dengan secara umum adalah :

Jantan : BB $=-739+1,772 \mathrm{~PB}-0,74 \mathrm{TP}+4,34 \mathrm{LD}-0,25$

$\mathrm{DaD}+1,15 \mathrm{LeD}+3,10 \mathrm{LK}+1,28 \mathrm{Tpi}$

Betina : $\mathrm{BB}=-578,7+0,628 \mathrm{~PB}+0,647 \mathrm{TP}+3,908$

$\mathrm{LD}+2,03 \mathrm{DaD}+1,87 \mathrm{LeD}+2,01 \mathrm{LK}-0,619 \mathrm{Tpi}$

Secara parsial panjang badan, tinggi pundak, lingkar dada, dalam dada, lebar dada, lingkar kanon dan tinggi pinggul sapi simbal jantan secara berurutan adalah $\mathrm{BB}$ $=-229+4,45 \mathrm{~PB}, \mathrm{BB}=-322+5,59 \mathrm{TP}, \mathrm{BB}=-515,7+$ $5,500 \mathrm{LD}, \mathrm{BB}=-182+10,83 \mathrm{DaD}, \mathrm{BB}=-30+9,32 \mathrm{LeD}$, $\mathrm{BB}=-290+33,50 \mathrm{LK}, \mathrm{BB}=-680+8,25 \mathrm{Tpi}$, sedangakan pada sapi simbal betina adalah $\mathrm{BB}=-176+4,004 \mathrm{~PB}, \mathrm{BB}$ $=-355+5,84 \mathrm{TP}, \mathrm{BB}=-458,8+5,006 \mathrm{LD}, \mathrm{BB}=-583+$ $18,05 \mathrm{DaD}, \mathrm{BB}=-272+15,43 \mathrm{LeD}, \mathrm{BB}=27,6+18,34 \mathrm{LK}$, $\mathrm{BB}=-636+7,75$ Tpi. Artinya penambahan $1 \mathrm{~cm}$ pada setiap ukuran-ukuran tubuh akan menaikan bobot badan sesuai dengan nilai koefsienya. Menurut Ikhsanuddin et al. (2018) bahwa $1 \mathrm{~cm}$ kenaikan setiap ukuran-ukuran tubuh akan menaikan bobot badan sesuai dengan nilai koefsien masing-masing ukuran tubuh. 
Tabel 4. Korelasi ukuran-ukuran tubuh dengan bobot badan

\begin{tabular}{lllccc}
\hline \multirow{2}{*}{ Variabel } & \multicolumn{1}{c}{ Sapi } & \multicolumn{4}{c}{ Jenis keamin } \\
\cline { 3 - 6 } & & \multicolumn{2}{c}{ Jantan } & \multicolumn{2}{c}{ Betina } \\
\cline { 3 - 6 } & Bali & 0,990 & 0,981 & 0,992 & 0,985 \\
Umum & Simbal & 0,919 & 0,844 & 0,973 & 0,947 \\
\multirow{2}{*}{ Panjang Badan - BB } & Bali & 0,941 & 0,885 & 0,956 & 0,913 \\
& Simbal & 0,567 & 0,321 & 0,607 & 0,368 \\
Tinggi Pundak - BB & Bali & 0,574 & 0,329 & 0,438 & 0,191 \\
& Simbal & 0,588 & 0,345 & 0,585 & 0,342 \\
Lingkar dada - BB & Bali & 0,927 & 0,859 & 0,982 & 0,964 \\
& Simbal & 0,898 & 0,806 & 0,956 & 0,913 \\
Dalam dada-BB & Bali & 0,926 & 0,857 & 0,970 & 0,940 \\
& Simbal & 0,586 & 0,343 & 0,771 & 0,594 \\
Lebar dada-BB & Bali & 0,883 & 0,779 & 0,909 & 0,826 \\
& Simbal & 0,593 & 0,351 & 0,698 & 0,487 \\
Lingkar Kanon - BB & Bali & 0,937 & 0,877 & 0,941 & 0,885 \\
& Simbal & 0,642 & 0,412 & 0,623 & 0,388 \\
Tinggi Pinggul - BB & Bali & 0,959 & 0,919 & 0,960 & 0,921 \\
& Simbal & 0,593 & 0,351 & 0,611 & 0,373 \\
\hline
\end{tabular}

Analisis korelasi keeratan hubungan antara ukuranukuran tubuh dengan bobot badan sapi bali jantan dan betina secara berurutan adalah 0,990 dan 0,992, sedangkan sapi simbal jantan dan betina secara berurutan adalah 0,919 dan 0,973. Nilai koefisisen determinasi ( $\mathrm{r}^{2}$ ) antara ukuran ukuran tubuh dengan bobot badan sapi bali jantan dan betina adalah 0,981 dan 0,985 . artinya $98,1 \%$ dan $98,5 \%$ bobot badan sapi bali dipengaruhi oleh ukuran-ukuran tubuh sedangkan sisanya dipengaruhi oleh faktor lain yang tidak teramati. Koefisisen determinasi $\left(\mathrm{r}^{2}\right)$ antara ukuran ukuran tubuh dengan bobot badan sapi simbal jantan dan betina adalah 0,844 dan 0,947 . Nilai determinasi ini menunjukkan bahwa $84,4 \%$ an $9,47 \%$ bobot badan sapi simbal dipengaruhi oleh ukuran-ukuran tubuh sedangkan sisanya dipengaruhi oleh faktor lain yang tidak teramati.

Secara parsial keeratan hubungan tertinggi antara ukuran ukuran tubuh dengan bobot badan adalah lingkar dada, dengan koefisien korelasi sapi bali jantan dan betina secara berurutan adalah 0,927 dan 0,982, sedangkan sapi simbal jantan dan betina secara berurutan adalah 0,898 dan 0,956 . Nilai koefisisen determinasi $\left(\mathrm{r}^{2}\right)$ antara ukuran-ukuran tubuh dengan bobot badan sapi bali jantan dan betina secara berurutan adalah o,859 dan 0,964 artinya 85,9\% dan 9,64\% bobot badan sapi bali dipengaruhi oleh ukuran-ukuran tubuh sedangkan sisanya dipengaruhi oleh faktor lain yang tidak teramati. Nilai koefisisen determinasi $\left(\mathrm{r}^{2}\right)$ antara ukuran-ukuran tubuh dengan bobot badan Simbal jantan dan betina secara berurutan adalah 0,806 dan 0,913 artinya artinya 80,6\% dan 91,3\% bobot badan sapi bali dipengaruhi oleh ukuranukuran tubuh sedangkan sisanya dipengaruhi oleh faktor lain yang tidak teramati. Artinya lingkar dada dapat digunakan untuk memperkirakan bobot badan ternak sapi bali dan sapi simbal. Hasil ini sesuai dengan penelitian Aguanta et al. (2019) bahwa lingkar dada memiliki koefisien korelasi yang paling tinggi terhadap bobot badan dengan nilai o,96 dan derajat determinasi $\left(\mathrm{r}^{2}\right)$ yaitu 0,939. Semakin tinggi ukuran lingkar dada mencerminkan bahwa ternak tersebut mempunyai bobot badan yang lebih tinggi (Takandjandji dan Sawitri, 2015). Hasil penelitian Gunawan dan Putera (2016) menunjukkan bahwa lingkar dada merupakan korelasi tertinggi dengan bobot badan. Korelasi yang tinggi antara lingkar dada dan bobot badan sapi dapat direkomendasikan bahwa seleksi terhadap lingkar dada akan memberikan hasil yang positif terhadap bobot badan dan secara praktis di lapangan mudah untuk dilakukan. Mahmudi et al. (2019) menyatakan bahwa lingkar dada merupakan penciri ukuran dan dalam dada sebagai penciri bentuk pada sapi bali. Ni'am et al. (2012) menyatakan bahwa lingkar dada pada setiap umur memiliki keeratan hubungan yang lebih baik dengan bobot badan jika dibandingkan dengan tinggi pundak, panjang badan dan lebar dada pada umur yang sama. untuk meningkatkan mutu genetik sapi bali paling efektif dilakukan terhadap lingkar dada dibandingkan dengan seleksi pada panjang (Warmadewi et al., 2017).

\section{SIMPULAN}

Karakteristik morfometrik sapi bali lebih rendah dibandingkan dengan sapi simbal. Faktor penentu ukuran tubuh sapi bali dan sapi simbal jantan dan betina adalah lingkar dada. Faktor penentu bentuk tubuh sapi bali jantan dan betina adalah tinggi pundak. Faktor penentu bentuk tubuh sapi simbal jantan adalah panjang badan, sedangkan sapi simbal betina adalah tinggi pundak. Korelasi antara ukuran-ukuran tubuh dengan bobot badan pada sapi bali dan sapi simbal baik jantan maupun betina yang tertinggi adalah lingkar dada.

\section{DAFTAR PUSTAKA}

Aguanta, F., T. Rozi dan Maskur. 2019. Karakteristik morfometrik (ukuran linier dan lingkar tubuh) sapi persilangan sumbawa $\mathrm{x}$ bali (sumbal) yang dipelihara secara semi intensif di kabupaten sumbawa. Jurnal Ilmu dan Teknologi. Peternakan Indonesia. Vol 5. No.1 Tahun 2019. P:17-26.

Ahmad, S.N., D.D. Siswansyah dan D.K. Swastika. 2004. Kajian sistem usaha ternak sapi potong di Kalimantan Tengah. Jurnal Pengkajian dan Pengembangan. Teknol. Pertanian. Vol 7. No.2 Tahun 2004. P:155-170. 
Baharun, A., H. L. L Belli dan T.M. Hine. 2017. Karakteristik pejantan muda sapi bali pada peternakan rakyat di desa Merbaun kabupaten Kupang. Jurnal Peternakan Nusantara Vol 3. No.1 Tahun 2017. P:11-16.

Depison. 2010. Performans anak hasil persilangan induk sapi bali dengan beberapa bangsa pejantan di kabupaten Batanghari Provinsi jambi. Jurnal Agribisnis Peternakan Vol 10. No.1 Tahun 2010. P:37-41.

Dewantari, M. dan A. A. Oka. 2020. Penampilan pedet sapi bali hasil inseminasi buatan dari pejantan berbeda. Majalah Ilmiah Peternakan Vol 23. No.1 Tahun 2020. P:39-42.

Gaspersz, V., 2006. Teknik analisis dalam penelitian percobaan. Pernerbit Tarsito, Bandung.

Gunawan, A., K. Jamal dan C. Sumantri. 2008. Pendugaan bobot badan melalui analisis morfometrik dengan pendekatan regresi terbaik best-subset pada domba garut tipe pedaging, tangkas dan persilangannya. Majalah Ilmiah. Peternakan. Vol 11. No.1 Tahun 2008. P:1-6.

Hamdani, M.D.I., K. Adhianto., Sulastri., A. Husni dan Renitasari. 2017. Ukuran-ukuran Tubuh Sapi Krui Jantan Dan Betina Di Kabupaten Pesisir Barat Lampung. Jurnal Ilmu Ternak. Vol 17. No.2 Tahun 2017. P:97-102.

Hamdani, M.D.I., A. Husni., M.T. Fajar dan Sulastri. 2018. Perbandingan performa kuantitatif sapi brahman cross di peternakan rakyat dengan di perusahaan komersial pada umur 18-24 bulan. Jurnal Ilmu dan Teknologi Peternakan Tropis. Vol 5. No.3 Tahum 2018. P:25-30.

Hikmawaty, A. Gunawan., R. Noor., dan Jakaria. 2014. Identifikasi ukuran tubuh dan bentuk tubuh sapi bali di beberapa pusat pembibitan melalui pendekatan analisis komponen utama. Jurnal Ilmu Produksi dan Teknologi. Hasil Peternakan. Vol 02. No.1 Tahun 2014. P:231-237.

Ikhsanuddin, V. Margareta., A. Nurgiartinigsih., Uswati dan Zainuddin. 2018. Korelasi ukuran tubuh terhadap bobot badan sapi aceh umur sapih dan umur satu tahun. Jurnal Agribisnis Peternakan Vol 18. No.2 Tahun 2018. P:117-122.

Mahmudi, M., R. Priyanto dan J. Jakaria. 2019. Karakteristik morfometrik sapi aceh, sapi po dan sapi bali berdasarkan analisis komponen utama (AKU). Jurnal Ilmu Produksi dan Teknologi Hasil Peternakan Vol 07. No.1 Tahun 2017. P:35-40.

Ni'am, H.U.M., A. Purnomoadi dan S. Dartosukarno. 2012. Hubungan antara ukuran-ukuran tubuh dengan bobot badan sapi bali betina pada berbagai kelompok umur. Junal Animal Agriculture. Vol 1. No.1 Tahun 2012. P:541-556

Putra. W.P.B. 2017. Teknik Persilangan Pada Sapi Belgian Blue (Bostaurus) Untuk Menghasilkan Bibit Unggul di Indonesia. Penerbit BioTrens, Bogor.

Takandjandji, M., dan R. Sawitri. 2015. Ukuran morfometrik banteng (bos javanicus d'alton, 1823) untuk menduga bobot badan. Jurnal Penelitian Hutan dan Konservasi Alam Vol 12. NO.1 Tahun 2015. P:59-73.

Trisnawanto., R. Adiwnatri., W.S. Dilaga. 2012. Hubungan antara ukuran-ukuran tubuh dengan bobot badan dombos jantan. Animal Agrculture Journal. Vol 1. No.1 Tahun 2012. P:653-668.

Warmadewi, A.D., G. L. Oka, dan I N. Ardika. 2017. Efektivitas seleksi dimensi tubuh sapi bali induk. Majalah Ilmiah Peternakan. Vol 20. No.1 Tahun 2017. P:16-19. 